Article

\title{
Assessing the Environmental and Economic Sustainability of Functional Food Ingredient Production Process
}

\author{
Anushree Priyadarshini ${ }^{1,2}\left(\mathbb{D}\right.$, Brijesh K. Tiwari $^{3}$ and Gaurav Rajauria ${ }^{4, *(1)}$ \\ 1 College of Business, Technological University Dublin, City Campus, Aungier Street, \\ D02 HW71 Dublin, Ireland; anushree.priyadarshini@tudublin.ie \\ 2 Environmental Sustainability and Health Institute, Technological University Dublin, Grangegorman, \\ D07 H6K8 Dublin, Ireland \\ 3 Department of Food Chemistry and Technology, Teagasc Food Research Centre, Ashtown, \\ D15 KN3K Dublin, Ireland; brijesh.tiwari@teagasc.ie \\ 4 Department of Biological \& Pharmaceutical Sciences, Munster Technological University, Clash, \\ V92 CX88 Tralee, Ireland \\ * Correspondence: gaurav.rajauria@mtu.ie
}

check for updates

Citation: Priyadarshini, A.; Tiwari, B.K.; Rajauria, G. Assessing the Environmental and Economic Sustainability of Functional Food Ingredient Production Process. Processes 2022, 10, 445. https:// doi.org/10.3390/pr10030445

Academic Editor: Dorota Jakubczyk

Received: 3 February 2022

Accepted: 21 February 2022

Published: 23 February 2022

Publisher's Note: MDPI stays neutral with regard to jurisdictional claims in published maps and institutional affiliations.

Copyright: (C) 2022 by the authors. Licensee MDPI, Basel, Switzerland. This article is an open access article distributed under the terms and conditions of the Creative Commons Attribution (CC BY) license (https:// creativecommons.org/licenses/by/ $4.0 /)$.

\begin{abstract}
Development and application of novel technologies in food processing is vital for ensuring the availability of adequate, safe, and convenient food with the desired quality and functional properties. Environmental and economic sustainability of technologies is essential prior to their application in the food processing sector. The objective of this research is to determine the environmental and economic feasibility of ultrasound-assisted extraction (UAE) for recovering functional food ingredients from seaweed. Experimental data is used to conduct a life cycle assessment (LCA) to investigate the environmental performance with a functional unit (FU) of obtaining $1 \mathrm{~g}$ of extracted polyphenols, measured as gallic acid equivalents ( $\mathrm{mg}$ GAE)/g seaweed. A life cycle impact assessment is performed with ReCiPe 2016 at midpoint. The cost of manufacturing (COM) of phenolic-rich extracts (as functional ingredient, bioactive, or nutraceutical) is estimated using time-driven activity-based costing (TDABC). The environmental profile findings show that across all categories, the UAE has considerably lower impacts than the conventional method, with electricity as the most important impact contributor, followed by solvent production. An economic assessment estimates the COM over a one-year period at a large scale using the UAE to be EUR 1,200,304, EUR 2,368,440, and EUR 4,623,290 for extraction vessel capacities of $0.05,0.1$, and $0.15 \mathrm{~m}^{3}$, respectively. Raw materials (including the type of raw material) and operational labour costs are the primary contributors to the COM. The findings thus present evidence to support the adoption of an environmentally and economically viable technology for functional ingredient production.
\end{abstract}

Keywords: bioactive; ultrasound-assisted extraction; cost of manufacturing; TDABC; nutraceutical; emerging technology; food processing; production process

\section{Introduction}

Nutraceuticals, or functional foods, are foods that not only provide essential nutrition but are also beneficial to health by reducing the risk of diseases [1]. These benefits of nutraceuticals are largely associated with the functional ingredients or bioactive (phytochemicals), especially to polyphenols, they contain. Polyphenols exert a wide range of biological activities that can protect the body against external factors. They can rinse the body of the reactive oxygen species formed in the case of some diseases, while in others they can stop the disease progression [2]. The importance of these bioactive polyphenols has been linked with many degenerative diseases and disorders, some of the prominent ones being cancer, metabolic problems, coronary heart disease, cold and cough, depression, and delayed gastrointestinal emptying. Research into these functional ingredients highlights their potential as constituents to be used in food products, thus creating added value for 
producers and benefits for consumer health [3]. Moreover, nutraceuticals are contributing towards the solution to the United Nations Sustainable Development Goals (SDGs) goals of sustainability, food security, and health [4].

Primarily, nutraceuticals are recovered from terrestrial plants, fruits, and vegetables, while attempts to find new sources to extract them are part of ongoing research on bioactives. In this vein, marine sources are extensively being explored for bioactive components as the marine environment contains enormous amounts of biodiversity with potential functional and nutraceutical capabilities $[5,6]$. The biodiversity of marine microflora is overwhelming owing to the secondary metabolites synthesized by the marine microflora and fauna and thus can be used as potential biotherapeutic agents [7]. Macroalgae (or seaweed), a renewable marine resource, is a commercially valuable source of bioactive compounds with therapeutic and preventative effects [8]. These are therefore increasingly used for manufacturing nutraceuticals or dietary supplements and are being exploited for the development of drugs for diabetes, microbial infections, and inflammation [9]. Exploring marine sources is in line with the EU's bioeconomy strategy and global systems-level policy agendas of sustainable food production and processing and foods for health [10]. The importance and market potential of this emerging area have been recognised globally and by the EU under initiatives such as blue bioeconomy and integrated marine plans such as harnessing our ocean wealth [11]. Ireland is among the top three seaweed biomass producing nations in Europe and produces approximately 40,000 tonnes per annum of seaweed.

With these initiatives, together with the advancements in qualitative and quantitative procedures, the extraction of bioactive compounds has also been greatly augmented. While conventional solvent extraction (CSE) involves maceration (or solvent extraction), Soxhlet or steam distillation advanced techniques such as ultrasound-assisted extraction (UAE), which is a non-thermal extraction technique that utilizes sound waves to induce pressure variations and cavitation as it migrates through a medium. As the sound waves are converted into mechanical energy, they disrupt the cell walls, decrease the particle size and increase the contact between the solvents and the targeted compounds [12]. It has been employed for extracting a number of functional ingredients from a range of plant sources as well as from micro and macroalgae [13]. As extraction yield and functionality of bioactive compounds is influenced by extraction techniques (e.g., heat or solvent use), increasingly advanced technologies are being used for extracting these beneficial compounds from marine sources such as seaweed. Moreover, conventional techniques/processes are more timeconsuming and energy-intensive; therefore, the focus is on developing novel techniques that are more efficient in terms of yield, time, and are environmentally friendly [14-16]. The development and application of novel technologies in food processing is particularly relevant to the objective of ensuring the availability of sufficient, safe, and convenient food with the desired quality and functional properties. Novel extraction technologies demonstrated potential for food and pharmaceutical applications for the extraction of bioactive compounds include enzyme-assisted extraction, microwave-assisted extraction, ultrasound-assisted extraction, and supercritical fluid extraction [13,17]. These technologies, commonly referred to as green extraction technologies, offer key advantages for advancing the extraction and processing of foods and for combatting the growing sustainability challenges of rising food demand [18]. However, a major challenge for the process industry in adopting these is to assess the environmental and economic sustainability of the processes involved $[16,19,20]$. A few life cycle assessment (LCA) studies have been conducted that have focused on evaluating design approaches [21-23] or full-scale production processes in the case of bioenergy production [24-27]. While these novel techniques are being utilized to identify and develop new and efficient extraction processes to valorise marine algal biomass, limited work has been performed to evaluate the environmental and economic sustainability of these processes [28,29].

In catering to the challenges in the coming decades of the rapidly expanding and more affluent population, the application of these technologies is essential; however, for assessing the practicality of any specific process, it is critical to conduct its environmental 
and economic evaluation [30,31]. Therefore, this study aims to conduct an environmental and economic evaluation of the novel technology, ultrasound-assisted extraction (UAE), for recovering bioactive (high-value-added phenolic-rich extracts) from seaweed. A few LCA studies focusing on UAE have highlighted the significance of exploring its environmental performance [32-34]. Due to UAE owing to advantages such as high extraction yield, less solvent consumption, low temperature usage, and greater efficiency in terms of energy consumption, UAE is increasingly being employed for extracting valuable compounds from different matrices [35-37]. Thus, to establish the potential of the novel technology UAE for producing a high-value-added bioactive from seaweed, this research aims to assess the environmental and economic sustainability of extraction processes.

\section{Materials and Methods}

\subsection{Recovery of Phenolic-Rich Extract from Seaweed}

Phenolic-rich extract from dried and milled brown seaweed was recovered by using conventional solvent extraction (CSE) and ultrasound assisted extraction (UAE) techniques outlined by Ummat et al. [38]. Conventional solvent extraction was carried out to compare the efficiency of the optimised UAE method. Figure 1 (below) presents a diagrammatic description of the process of extracting phenolic-rich extract from seaweed using UAE.

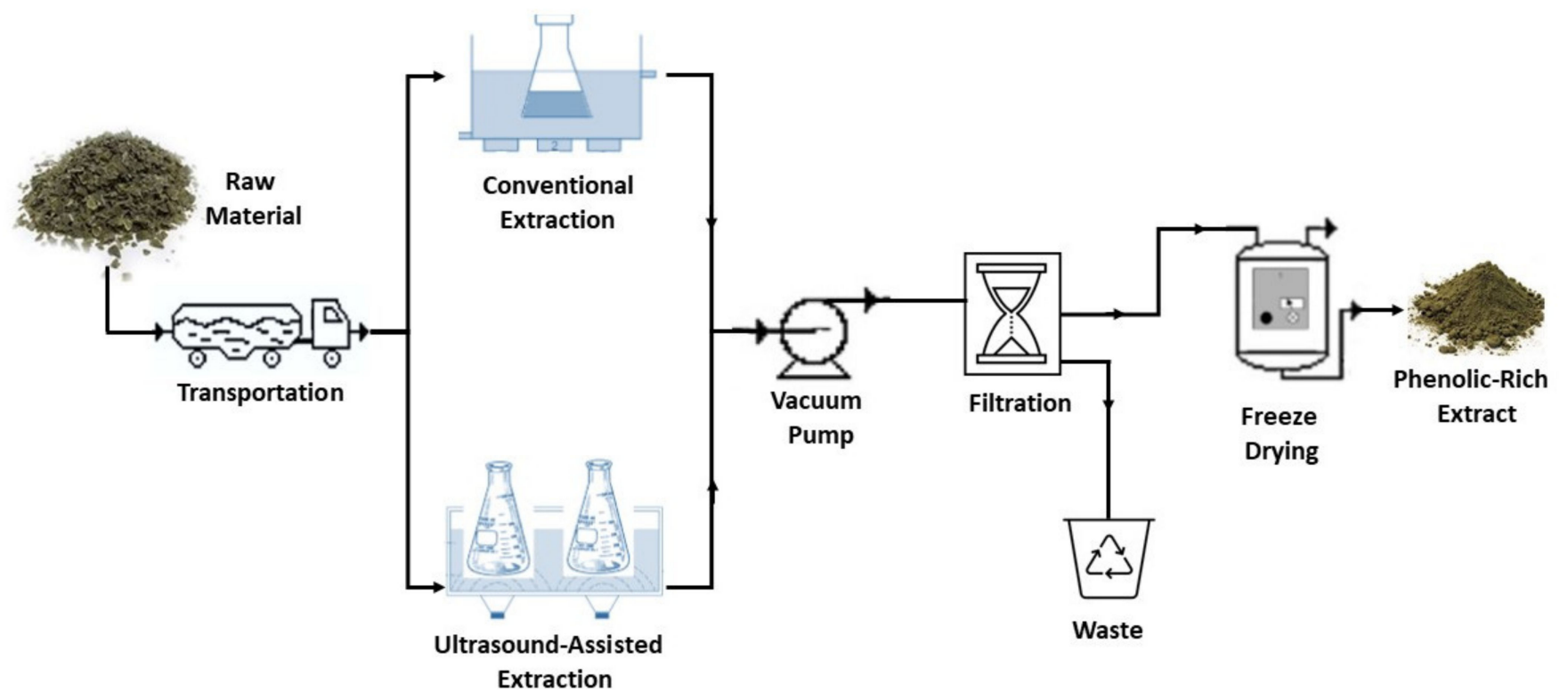

Figure 1. Schematic representation of the extraction process for the recovery of phenolic-rich extract from seaweed.

\subsection{Environmental Assessment}

The mandatory principles as per ISO standards (ISO 14040) [39] were followed in this study, and the included steps were the following: goal and scope definition, life cycle inventory, and life cycle impact assessment and interpretation.

\subsubsection{Goal and Scope Definition}

The goal of this study was to evaluate and compare the environmental impacts of a lab-scale CSE and UAE of polyphenols from seaweed. A gate-to-gate LCA was performed considering the system boundaries as described in Figure 2. No infrastructure-related processes, such as the production of lab-scale equipment, as well as no transportation of any of the materials involved, were included. 


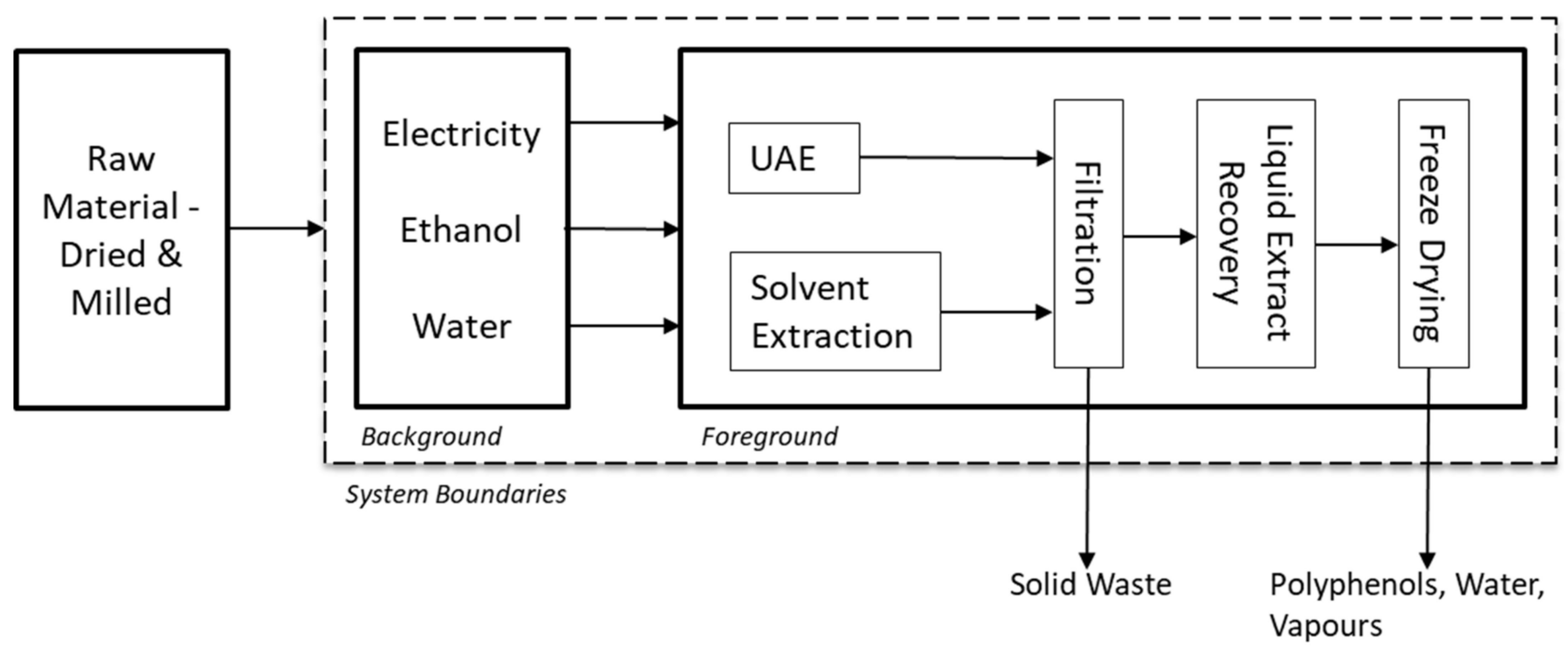

Figure 2. Schematic representation of the studied system boundary (dashed line).

The functional unit (FU) was defined as obtaining $1 \mathrm{~g}$ of extracted polyphenols, measured as gallic acid equivalents (mg GAE)/g seaweed. An effective comparison of the extraction methods could be carried out using this FU by considering their technical efficiency expressed as extraction yields. All entries in the inventory were stated to this FU.

\subsubsection{Life Cycle Inventory}

The life cycle inventory was modelled using generic data from databases and experimental data as presented in Table 1. Generic data, as well as associated impacts, were sourced from the Environment Footprint (EF) database (version 3) using the openLCA 1.10.3 software (GreenDelta GmbH, Berlin, Germany). Experimental data was used for raw material and solvent inventories. Moreover, electricity consumption of all equipment was ascertained by recording their operation time and power ratings.

Table 1. Life cycle inventory data for extraction processes (per g polyphenols).

\begin{tabular}{lcccc}
\hline Inventory & Unit & CSE & UAE & Data Source/Remark \\
\hline Inputs & & & & Measured \\
\hline Seaweed & $\mathrm{gm}$ & 28.79 & 4.98 & Measured \\
Ethanol & $\mathrm{gm}$ & 115.17 & 19.91 & Measured \\
Water & $\mathrm{L}$ & 0.14 & 0.02 & Measured \\
Electricity for extraction & $\mathrm{kWh}$ & 2.76 & 0.01 & Measured \\
Electricity for filtration & $\mathrm{kWh}$ & 0.02 & 0.002 & Measured \\
Electricity for freeze drying & $\mathrm{kWh}$ & 138.89 & 24.01 & \\
Outputs & & & & \\
\hline Polyphenols & $\mathrm{g}$ & 1 & 1 & \\
Evaporated ethanol & $\mathrm{g}$ & 11.52 & 1.99 & Calculated for experiments from mass balance. Assuming 10\% loss \\
Recovered ethanol & $\mathrm{g}$ & 103.65 & 17.92 & Considers a 90\% ethanol recovery rate \\
Solid waste & $\mathrm{g}$ & 25.57 & 3.23 & Calculated from mass balance \\
Wastewater & $\mathrm{L}$ & 0.14 & 0.02 & Assuming all water used was finally considered as wastewater \\
\hline
\end{tabular}

CSE: Conventional solvent extraction; UAE: Ultrasound assisted extraction.

\subsubsection{Life Cycle Impact Assessment}

The life cycle impact assessment was performed using ReCiPe 2016 method at midpoint level. The impact categories evaluated were the following: Fine particulate matter formation; Freshwater ecotoxicity; Human carcinogenic toxicity; Human non-carcinogenic 
toxicity; Marine ecotoxicity; Marine eutrophication; Mineral resource scarcity; Ozone formation, Human health; Ozone formation, Terrestrial ecosystems; Terrestrial acidification; Terrestrial ecotoxicity and Water consumption.

\subsection{Economic Assessment}

Experimental data from Ummat et al. [38] was used to estimate the cost of manufacturing (COM) of phenolic-rich extracts by using time-driven activity-based costing (TDABC) methodology. TDABC is a bottom-up costing methodology presented by Kaplan and Anderson [40] that identifies the cost drivers in processes and has been demonstrated to have utility in production and service industries [41]. Activities are the fundamental cost objects in this process [42] and these costs are combined with any additional occurring costs. This method has been described as providing a more accurate and transparent means of calculating costs than a top-down approach [43]. The COM, covering the different activities during the extraction process as outlined in Figure 3, was determined by using the following equations below:

$$
\mathrm{COM}=\mathrm{X}_{1}+\mathrm{X}_{2}+\mathrm{X}_{3}+\mathrm{X}_{4}+\mathrm{X}_{5}+\mathrm{X}_{6}
$$

where:

$\mathrm{COM}=$ Cost of manufacturing

$\mathrm{X}_{1}=$ Operational cost of workers

$\mathrm{X}_{2}=$ Raw material cost

$\mathrm{X}_{3}=$ Extraction cost

$\mathrm{X}_{4}=$ Filtration cost

$X_{5}=$ Extract drying cost

$\mathrm{X}_{6}=$ Waste treatment cost

$$
\mathrm{X}_{1}=\sum_{\mathrm{k}=1}^{\mathrm{n}} \mathrm{W} \times\left(\mathrm{R}_{\mathrm{h}} \times \mathrm{H}_{\mathrm{W}}\right)
$$

where:

$\mathrm{W}=$ Number of workers

$R_{h}=$ Hourly rate of workers (EUR/h)

$\mathrm{H}_{\mathrm{W}}=$ Number of hours worked

$\mathrm{X}_{2}=\sum_{\mathrm{k}=1}^{\mathrm{n}} \mathrm{RM} \times \mathrm{R}_{\mathrm{RM}}+\sum_{\mathrm{k}=1}^{\mathrm{n}} \mathrm{C}_{\mathrm{DO}}+\left(\mathrm{W}_{\mathrm{DO}} \times \mathrm{RT} \times \mathrm{R}_{\mathrm{E}}\right)+\sum_{\mathrm{k}=1}^{\mathrm{n}} \mathrm{C}_{\mathrm{MM}}+\left(\mathrm{W}_{\mathrm{MM}} \times \mathrm{RT} \times \mathrm{R}_{\mathrm{E}}\right)$

where:

$\mathrm{RM}=$ Raw material quantity $\mathrm{k}(\mathrm{kg})$

$\mathrm{R}_{\mathrm{RM}}=$ Rate of raw material (EUR $/ \mathrm{kg}$ )

$\mathrm{C}_{\mathrm{DO}}=$ Cost of dryer oven of size $\mathrm{k}$ (EUR)

$\mathrm{W}_{\mathrm{DO}}=$ Wattage of dryer oven $(\mathrm{kW})$

$\mathrm{RT}=$ Runtime (h)

$\mathrm{R}_{\mathrm{E}}=$ Electricity rate $(\mathrm{EUR} / \mathrm{kWh})$

$\mathrm{C}_{\mathrm{MM}}=$ Cost of milling machine of size $\mathrm{k}$ (EUR)

$\mathrm{W}_{\mathrm{MM}}=$ Wattage of milling machine $(\mathrm{kW})$

$$
\mathrm{X}_{3}=\sum_{\mathrm{k}=1}^{\mathrm{n}} \mathrm{S}_{1} \times \mathrm{R}_{\mathrm{S} 1}+\sum_{\mathrm{k}=1}^{\mathrm{n}} \mathrm{S}_{2} \times \mathrm{R}_{\mathrm{S} 2}+\sum_{\mathrm{k}=1}^{\mathrm{n}} \mathrm{C}_{\mathrm{V}}+\left(\mathrm{W}_{\mathrm{V}} \times \mathrm{RT} \times \mathrm{R}_{\mathrm{E}}\right)
$$

where:

$\mathrm{S}_{1}=$ Solvent 1 volume $\mathrm{k}(\mathrm{kg})$

$\mathrm{R}_{\mathrm{S} 1}=$ Rate of Solvent 1 volume $\mathrm{k}(\mathrm{EUR} / \mathrm{kg})$

$\mathrm{S}_{2}=$ Solvent $2(\mathrm{~kg})$

$\mathrm{R}_{\mathrm{S} 2}=$ Rate of Solvent $2(\mathrm{EUR} / \mathrm{kg})$

$\mathrm{C}_{\mathrm{V}}=$ Cost of vessel of size $\mathrm{k}$ (EUR)

$\mathrm{W}_{\mathrm{V}}=$ Wattage of vessel $(\mathrm{kW})$

$\mathrm{RT}=$ Runtime (h)

$\mathrm{R}_{\mathrm{E}}=$ Electricity rate $(\mathrm{EUR} / \mathrm{kWh})$ 


$$
\mathrm{X}_{4}=\sum_{\mathrm{k}=1}^{\mathrm{n}} \mathrm{CC} \times \mathrm{R}_{\mathrm{CC}}+\sum_{\mathrm{k}=1}^{\mathrm{n}} \mathrm{C}_{\mathrm{VP}}+\left(\mathrm{W}_{\mathrm{VP}} \times \mathrm{RT} \times \mathrm{R}_{\mathrm{E}}\right)
$$

where:

$\mathrm{CC}=$ Cheesecloth of length $\mathrm{k}(\mathrm{m})$

$\mathrm{R}_{\mathrm{CC}}=$ Rate of cheesecloth $(\mathrm{EUR} / \mathrm{m})$

$\mathrm{C}_{\mathrm{VP}}=$ Cost of vacuum pump of size $\mathrm{k}(\mathrm{EUR})$

$\mathrm{W}_{\mathrm{VP}}=$ Wattage of vacuum pump $(\mathrm{kW})$

$\mathrm{RT}=$ Runtime (h)

$\mathrm{R}_{\mathrm{E}}=$ Electricity rate $(\mathrm{EUR} / \mathrm{kWh})$

$$
\mathrm{X}_{5}=\sum_{\mathrm{k}=1}^{\mathrm{n}} \mathrm{C}_{\mathrm{FD}}+\left(\mathrm{W}_{\mathrm{FD}} \times \mathrm{RT} \times \mathrm{R}_{\mathrm{E}}\right)+\sum_{\mathrm{k}=1}^{\mathrm{n}} \mathrm{C}_{\mathrm{VP}}+\left(\mathrm{W}_{\mathrm{VP}} \times \mathrm{RT} \times \mathrm{R}_{\mathrm{E}}\right)
$$

where:

$\mathrm{C}_{\mathrm{FD}}=$ Cost of freeze dryer of size $\mathrm{k}(\mathrm{EUR})$

$\mathrm{W}_{\mathrm{FD}}=$ Wattage of freeze dryer $(\mathrm{kW})$

$\mathrm{C}_{\mathrm{VP}}=$ Cost of vacuum pump of size $\mathrm{k}(\mathrm{EUR})$

$\mathrm{W}_{\mathrm{VP}}=$ Wattage of vacuum pump $(\mathrm{kW})$

$\mathrm{RT}=$ Runtime $(\mathrm{h})$

$\mathrm{R}_{\mathrm{E}}=$ Electricity rate $(\mathrm{EUR} / \mathrm{kWh})$

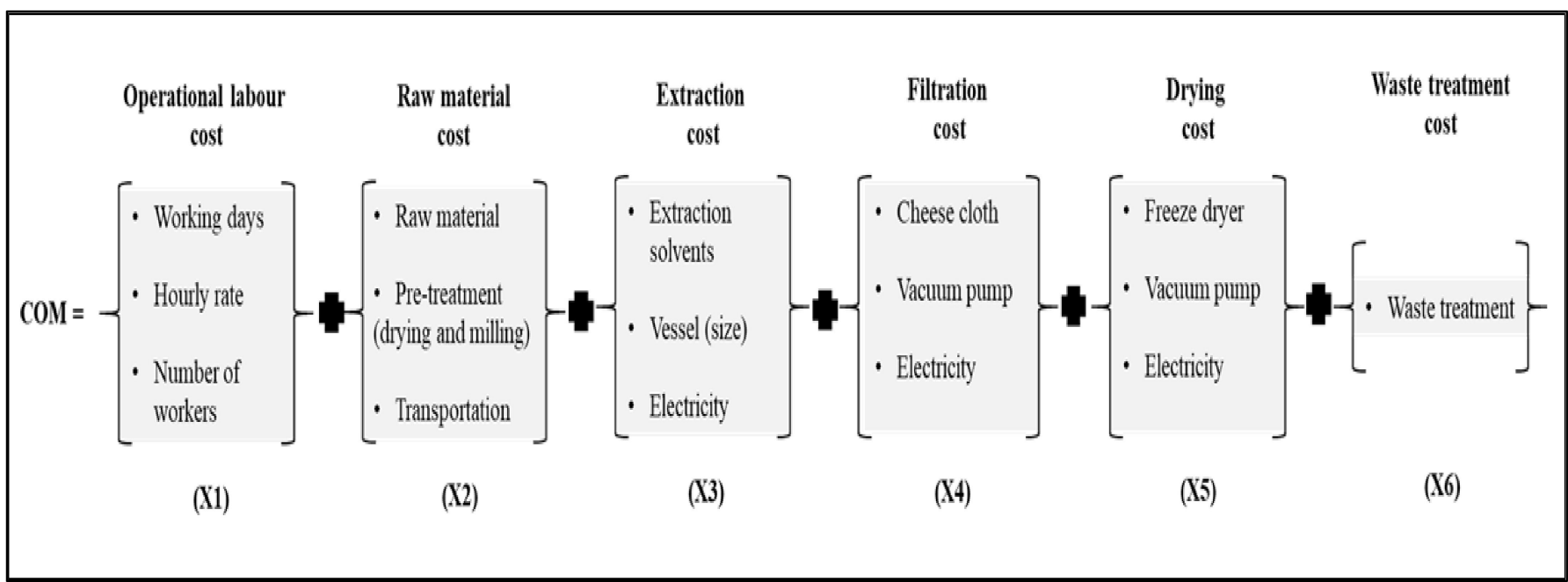

Figure 3. Schematic representation of various activities during the extraction process.

\subsubsection{Lab Scale}

The economic parameters used for assessing the cost of manufacturing phenolic-rich extracts are outlined in Table 2. The COM of phenolic-rich extracts on lab scale using both CSE and UAE was determined. A vessel size of $0.01 \mathrm{~m}^{3}$ for both shaking water bath and ultrasonic bath was used. The costs of vessels as provided by Fisher Scientific (Ballycoolen, Dublin, Ireland) and Elma Schmidbauer GmbH (Gottlieb-Daimler-Straße, Singen, Germany) were EUR 1980 and EUR 2440, respectively. At lab scale the run time for conventional solvent extraction is $24 \mathrm{~h}$ ( 1 cycle per day), while for UAE, given its run time of $30 \mathrm{~min}$ it was estimated that instrument could run for 4 cycles/day ( 8 working hours). The total operational time at lab scale would involve 1 shift for 253 working days/year (for Ireland), requiring one person for each technology. 
Table 2. Economic parameters used for cost of manufacturing (COM) estimation.

\begin{tabular}{|c|c|}
\hline Parameters & Rate (Ex VAT) \\
\hline Pre-treated raw material (dried, milled and transportation) ${ }^{a}$ & EUR $27.72 / \mathrm{kg}$ \\
\hline \multicolumn{2}{|l|}{ Industrial ultrasound units/vessels a } \\
\hline $50 \mathrm{~L}\left(0.05 \mathrm{~m}^{3}\right)$ & EUR 12,360 \\
\hline $100 \mathrm{~L}\left(0.10 \mathrm{~m}^{3}\right)$ & EUR 15,175 \\
\hline $150 \mathrm{~L}\left(0.15 \mathrm{~m}^{3}\right)$ & EUR 16,975 \\
\hline Labour ${ }^{b}$ & EUR 9.80/h \\
\hline For $50 \mathrm{~L}$ & 1 operator \\
\hline For $100 \mathrm{~L}$ & 2 operators \\
\hline For $150 \mathrm{~L}$ & 3 operators \\
\hline \multicolumn{2}{|l|}{ Extraction solvents ${ }^{a}$} \\
\hline Ethanol & EUR $15.10 / \mathrm{kg}$ \\
\hline Water ${ }^{c}$ & EUR $1.21 / \mathrm{kg}$ \\
\hline Electricity cost ${ }^{\mathrm{d}}$ & EUR $0.2122 / \mathrm{kWh}$ \\
\hline \multicolumn{2}{|c|}{ Filtration cost (including cheese cloth, vacuum pump, and electricity cost) ${ }^{a}$} \\
\hline Cheese cloth & EUR 2.5/metre \\
\hline Vacuum pump & EUR 1893 \\
\hline \multicolumn{2}{|c|}{ Freeze drying cost (including 6L freeze dryer, vacuum pump, and electricity cost) } \\
\hline Freeze dryer (6L, fully assembled unit) & EUR 18,495 \\
\hline Vacuum pump & EUR 2206 \\
\hline Waste treatment cost ${ }^{\mathrm{e}}$ & Nil \\
\hline
\end{tabular}

The cost of raw materials including pre-treatment (drying and milling) as well as transportation to the site was EUR 27.72/kg (Quality Sea Veg., Co. Donegal, Ireland). The cost of the extraction solvent ethanol was EUR 15.10/kg (Fisher Scientific, Dublin, Ireland) and cost of water for commercial usage was EUR 1.21/ kg (Irish Water). The capital costs of the filtration vacuum pump (Fisher Scientific, Ireland) and the freeze dryer (Mason Technologies, Ireland) were EUR 1893 and EUR 20,701, respectively. The cost of the cheese cloth used for filtration was EUR 2.5/metre. An electricity cost of $0.2122 / \mathrm{kWh}$ was considered based on the current electricity costs in Ireland. The residual waste contains nutrients that are beneficial for crop growth, improving soil tilth, increasing aeration, water holding capacity, soil biological activity, and reducing erosion by wind and water. Therefore, cost of discarding organic residue in the soil was neglected as this cost is considered negligible in comparison to other disposal methods [44,45].

\subsubsection{Large Scale}

Three UAE extraction vessels with different volumes $\left(0.05,0.10\right.$, and $\left.0.15 \mathrm{~m}^{3}\right)$ were also evaluated to produce polyphenol-rich extract on a large scale. The individual costs of these vessels as provided by Elma Schmidbauer $\mathrm{GmbH}$ (Hohentwiel, Germany), were EUR 12,360, EUR 15,175, and EUR 16,974, respectively. Time of extraction and the solvent to raw material ratio are the two process parameters that must remain constant in order to satisfy the assumption that the industrial-scale process produces the same yield as the laboratory scale [46]. The scale-up from the laboratory to the industrial-scale under the same conditions often increases the extraction yield, but in this study, it was assumed that the yield was identical at both the laboratory and industrial scales [47,48]; therefore, the industrial-scale processes were assumed to have the same yield and extraction time as the laboratory-scale process. Given the run time of $30 \mathrm{~min}$ followed by filtration and vessel preparation for next run, it was estimated that the process could run for 12 cycles/day and the total operational time would involve three daily shifts for 330 days, or $7920 \mathrm{~h}$ per year [46]. The number of operators required per shift would vary according to the capacity of the plant, with 1 person per shift needed (assuming working at full-time capacity) for $0.05 \mathrm{~m}^{3}$ vessel capacity, 2 persons per shift for $0.10 \mathrm{~m}^{3}$, and 3 persons per shift for $0.15 \mathrm{~m}^{3}$ 
vessel capacity. All other parameters for calculating the COM on a large scale were as described above for lab scale.

\section{Results and Discussion}

\subsection{Environmental Assessment of the Extraction Processes}

The environmental profiles for the extraction processes presented in Table 3 highlight that across all categories, a higher impact is generated by CSE against the UAE technique. This shows that, for the experimental conditions utilized in this study, UAE has considerably lower impacts than the conventional method. For instance, fine particulate matter formation is 8 times more in the case of CSE than of UAE. Similarly, ozone formation adversely impacting both human health and terrestrial ecosystems is about 6 times more in the case of CSE than in UAE. Moreover, CSE causes six times the terrestrial acidification and consumes seven times more water than UAE uses when extracting polyphenols from seaweed using the outlined experimental conditions. Given the use of marine biomass for extracting polyphenols, no land use impact was observed in the case of either CSE or UAE. It is also noteworthy that no global warming impact was observed. Modahl et al. [26] also reported $1 \mathrm{~kg} \mathrm{CO}_{2}$ eq. in the extraction of vanillin when considering weight as a functional unit. As outlined in Figure 4, it was observed that in the case of both CSE and UAE, electricity was the most important impact contributor in all categories, followed by solvent production. This was due to electricity being used to operate a range of equipment in the extraction process, and solvent being the only waste generated in both cases.

Table 3. Environmental profiles for the extraction processes (per functional unit of $1 \mathrm{~g}$ polyphenols).

\begin{tabular}{lccc}
\hline Impact Category & Unit & CSE & UAE \\
\hline Fine particulate matter formation (FPMF) & $\mathrm{kg} \mathrm{PM2.5} \mathrm{eq}$ & $7.55 \times 10^{-5}$ & $1.28 \times 10^{-5}$ \\
Freshwater ecotoxicity (FE) & $\mathrm{kg} \mathrm{1,4-DCB}$ & $2.94 \times 10^{-7}$ & $4.98 \times 10^{-8}$ \\
Human carcinogenic toxicity (HCT) & $\mathrm{kg} \mathrm{1,4-DCB}$ & $2.07 \times 10^{-6}$ & $3.52 \times 10^{-7}$ \\
Human non-carcinogenic toxicity (HNCT) & $\mathrm{kg}$ 1,4-DCB & $1.75 \times 10^{-4}$ & $2.97 \times 10^{-5}$ \\
Marine ecotoxicity (MECo) & $\mathrm{kg} \mathrm{1,4-DCB}$ & $9.72 \times 10^{-4}$ & $1.65 \times 10^{-4}$ \\
Marine eutrophication (MEut) & $\mathrm{kg} \mathrm{N} \mathrm{eq}$ & $6.66 \times 10^{-9}$ & $1.13 \times 10^{-9}$ \\
Mineral resource scarcity (MRS) & $\mathrm{kg} \mathrm{Cu} \mathrm{eq}$ & $2.31 \times 10^{-3}$ & $3.92 \times 10^{-4}$ \\
Ozone formation, Human health (OFHH) & $\mathrm{kg} \mathrm{NOx} \mathrm{eq}$ & $6.80 \times 10^{-4}$ & $1.15 \times 10^{-4}$ \\
Ozone formation, Terrestrial ecosystems (OFTE) & $\mathrm{kg} \mathrm{NOx} \mathrm{eq}$ & $6.80 \times 10^{-4}$ & $1.15 \times 10^{-4}$ \\
Terrestrial acidification (TA) & $\mathrm{kg} \mathrm{SO2} \mathrm{eq}$ & $2.45 \times 10^{-4}$ & $4.16 \times 10^{-5}$ \\
Terrestrial ecotoxicity (TECo) & $\mathrm{kg} \mathrm{1,4-DCB}$ & $1.44 \times 10^{-4}$ & $2.45 \times 10^{-5}$ \\
Water consumption (WC) & $\mathrm{m}{ }^{3}$ & $1.44 \times 10^{-4}$ & $2.49 \times 10^{-5}$ \\
\hline
\end{tabular}

CSE: conventional solvent extraction; UAE: ultrasound-assisted extraction.

\subsection{Economic Assessment of the Extraction Processes using Extraction Yield}

The COM of phenolic-rich extracts obtained using CSE and UAE techniques was estimated by including costs of inputs (pre-treated raw material, transportation, extraction solvent, vessel cost, filtration, freeze-drying) and operational costs (electricity, labour). Operational site/building costs were not included. Using time-driven activity-based costing (TDABC), the cost was estimated over a one-year operational period. This included listing the various activities involved in the extraction process and their costs were accessed for the duration of the activity.

The costs for manufacturing over a one-year period at laboratory scale were estimated (using Equation (1)) to be EUR 65,513 for UAE based on an extraction vessel capacity of $0.01 \mathrm{~m}^{3}$. This cost comprises the pre-treated raw material cost (EUR 5611), the cost of extraction (EUR 15,752), the cost of filtration (EUR 3182), the cost of freeze drying (EUR 21,133), and the cost of operational labour (EUR 19,835) using Equations (2)-(6). While using the CSE technique, the extraction cost for a year at lab scale for the same vessel capacity was estimated at EUR 50,897. This cost comprises the pre-treated raw material cost (EUR 1402), the cost of extraction (EUR 6312), the cost of filtration (EUR 2215), the 
cost of freeze drying (EUR 21,133), and the cost of operational labour (EUR 19,835) using Equations (2)-(6). The overall COM per year at lab scale is higher in the case of UAE because of the four extraction cycles per day as against one cycle per day in the case of the conventional method. However, owing to the higher extraction yield in UAE (35.1\%) compared to the conventional method (11.2\%), the COM EUR $/ \mathrm{kg}$ extract is lower for UAE at EUR $922 / \mathrm{kg}$ than for CSE at EUR $8981 / \mathrm{kg}$. The COM per $\mathrm{kg}$ of phenolic-rich extracts at the lab scale for both CSE and UAE are summarized in Table 4.

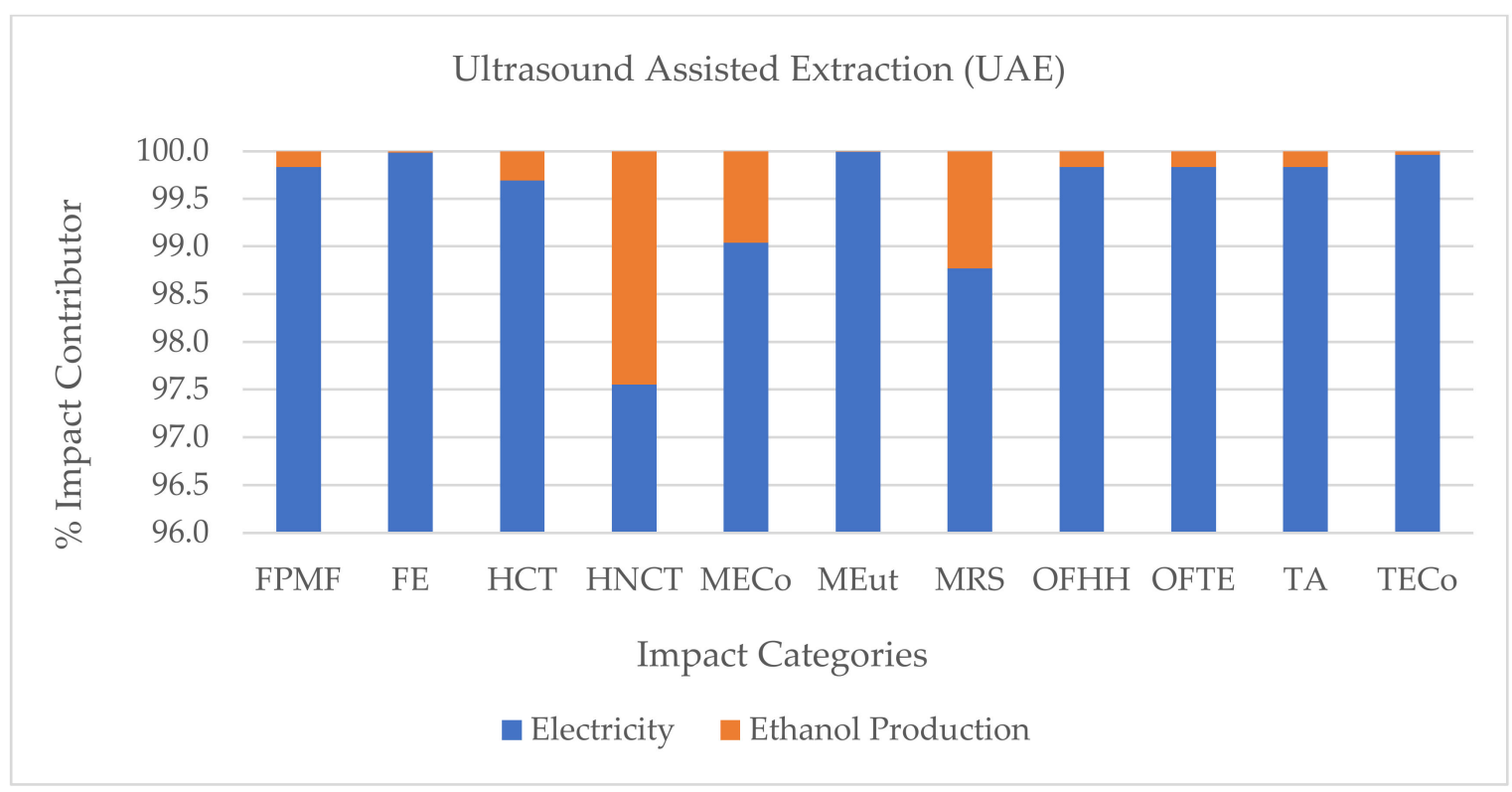

(a)

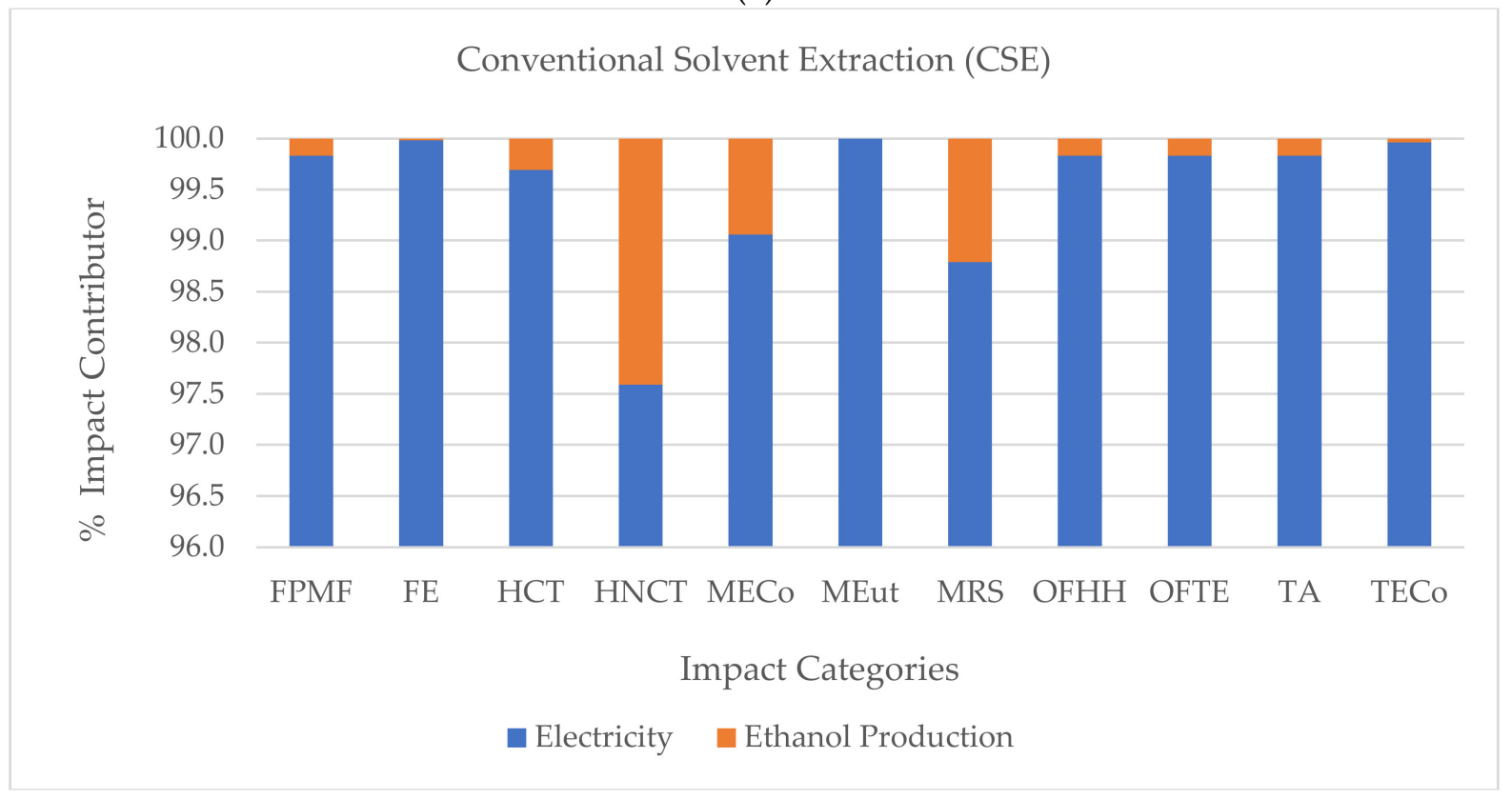

(b)

Figure 4. The environmental profile of (a) ultrasound-assisted extraction (UAE) and (b) conventional solvent extraction (CSE) processes. Abbreviation of impact categories are as follows: FPMF (Fine particulate matter formation), FE (Freshwater ecotoxicity), HCT (Human carcinogenic toxicity), HNCT (Human non-carcinogenic toxicity), MECo (Marine ecotoxicity), MEut (Marine eutrophication), MRS (Mineral resource scarcity), OFHH (Ozone formation, Human health), OFTE (Ozone formation, Terrestrial ecosystems), TA (Terrestrial acidification), and TECo (Terrestrial ecotoxicity). 
Table 4. COM of extract and TPC using CSE and UAE at lab and large scale.

\begin{tabular}{|c|c|c|c|c|c|}
\hline & $\begin{array}{l}\text { Extraction } \\
\text { Yield (\%) }\end{array}$ & $\begin{array}{c}\mathrm{TPC} \\
(\mathrm{mg} / \mathrm{g})\end{array}$ & $\begin{array}{c}\text { Vessel } \\
\text { Capacity }\left(\mathrm{m}^{3}\right)\end{array}$ & $\begin{array}{l}\text { COM of Extract } \\
\text { (EUR/kg) }\end{array}$ & $\begin{array}{c}\text { COM of } \\
\text { Total Polyphenols (EUR/kg) }\end{array}$ \\
\hline \multicolumn{6}{|c|}{ Lab Scale } \\
\hline CSE & 11.2 & 310.11 & 0.01 & 8981 & 28,961 \\
\hline UAE & 35.1 & 572.33 & 0.01 & 922 & 1611 \\
\hline \multicolumn{6}{|c|}{ Large Scale } \\
\hline UAE & - & - & 0.05 & 345 & 603 \\
\hline UAE & - & - & 0.10 & 340 & 595 \\
\hline UAE & - & - & 0.15 & 443 & 774 \\
\hline
\end{tabular}

The COM over a one-year period at large scale using UAE was estimated (using Equation (1)) to be EUR 1,200,304 for the extraction vessel capacities of $0.05 \mathrm{~m}^{3}$, this cost included the pre-treated raw material cost (EUR 274,428), the cost of extraction (EUR 659,875), the cost of filtration (EUR11,889), the cost of freeze drying (EUR 21,264), and the cost of operational labour (EUR 232,848). The COM for the extraction vessel capacity $0.1 \mathrm{~m}^{3}$ was EUR 2,368,440, and this included the pre-treated raw material cost (EUR 548,856), the cost of extraction (EUR 1,310,835), the cost of filtration (EUR 21,789), the cost of freeze drying (EUR 21,264), and the cost of operational labour (EUR 465,696). For the $0.15 \mathrm{~m}^{3}$ extraction vessel capacity the COM was EUR 4,623,290, comprising the pre-treated raw material cost (EUR 823,284), the cost of extraction (EUR 3,048,509), the cost of filtration (EUR 31,689), the cost of freeze drying (EUR 21,264), and the cost of operational labour (EUR 698,544). At the large scale, using extraction yield, the COM per $\mathrm{kg}$ of phenolic-rich extract was also calculated, and it was observed that the COM was the lowest for the $0.10 \mathrm{~m}^{3}$ vessel capacity, at EUR $340 / \mathrm{kg}$, followed by the COM for a vessel capacity of $0.05 \mathrm{~m}^{3}$ at EUR $345 / \mathrm{kg}$, while the highest COM was observed for a processing capacity of $0.15 \mathrm{~m}^{3}$, at EUR $443 / \mathrm{kg}$. The COM per kg of phenolic-rich extracts on a large scale for both CSE and UAE are summarized in Table 4.

\subsection{Economic Assessment of the Extraction Processes Using Total Phenolic Content}

The health benefits derived from the extract are mainly attributed to the amount of total phenolic content of the extract [49-51]. The concentration of TPC in the extract helps to determine the dosage of extract required in the development of nutraceutical or functional foods. Therefore, the COM of the extract based upon the total phenolic content in the extract was also calculated. At lab scale $\left(0.01 \mathrm{~m}^{3}\right.$ vessel capacity), the COM for UAE was estimated at EUR $1611 / \mathrm{kg}$ using TPC (572 $\mathrm{mg} / \mathrm{g}$ of extract) and the COM for conventional extraction was EUR $28,961 / \mathrm{kg}$ using TPC (310 $\mathrm{mg} / \mathrm{g}$ of extract). While on a large scale, the COM for the UAE was a minimum of EUR $595 / \mathrm{kg}$ for a $0.10 \mathrm{~m}^{3}$ vessel capacity and a maximum of EUR 774 for a $0.15 \mathrm{~m}^{3}$ vessel capacity. The COM of the extract based upon the total phenolic content in the extract at lab scale as well as at large scale using both CSE and UAE are summarized in Table 4. Compared to lab scale, while it is observed that the COM was lower at large scale vessel capacities, it is noteworthy that the COM did not reduce with the increasing vessel size.

The economic evaluation demonstrated that the cost of raw materials and operational labour costs have a significant impact on the COM to produce extracts using different vessel sizes. Saravacos and Maroulis [52] also highlight that in food production processes, the key cost items are raw materials and labour costs. Similar observations with regard to raw materials being the major component of the cost of manufacturing were made in the case of volatile oil extracted from Aquilaria sinensis using supercritical carbon dioxide [53]. Although extraction yield had a large influence on the COM, the phenolic concentration in the extract was identified as a key parameter in the economic evaluation carried out. The estimated COM was a minimum of using a $0.1 \mathrm{~m}^{3} \mathrm{UAE}$ vessel capacity. Prior research 
also highlights that in the case of producing extracts, COM is impacted by the extraction vessel capacity [54-56]. Overall, it is economically feasible to operate an industrial scale ultrasound extraction plant to recover phenolic compounds from seaweed, even at a small scale of production. Similar results confirming the feasibility of industrial usage of novel technology, supercritical fluid extraction, for producing extracts from grape bagasse were outlined by Farias-Campomanes et al. [46]. However, it is recommended that a full profiling of phenolic compounds in the extract should be carried out prior to its utilization for commercial applications. Prior research also indicates that COM is strongly influenced by raw material $[57,58]$, hence it can be anticipated that seaweed species (as their phenolic content varies) may have an impact on the COM.

\section{Conclusions}

Nutraceuticals are being widely used for promoting health, and the potential of marine algae as a valuable source of these bioactive compounds with therapeutic effects is being increasingly recognized. While the natural renewable resource seaweed (marine algae) is a rich source of dietary fibres, polyunsaturated fatty acids, polysaccharides, and vitamins, to better exploit their potential, novel extraction technologies are being utilized. This study evaluated the environmental and economic viability of using the novel extraction technology UAE for extracting bioactives from seaweed. UAE offers benefits such as increased yield and decreased extraction time, it was better than the conventional extraction techniques in terms of a reduction in one-fourth the extraction time (based on per extraction cycle) and providing almost 1.8 times higher yield. With raw materials and operational labour costs being the primary contributors to the COM, it has considerably lower environmental impacts than the conventional extraction method, with electricity being the most important impact contributor.

Advancements in extraction technologies have burgeoned in every aspect of food processing and have led to progress in their scientific applications, but they call for environmental and economic assessment and policy development for widespread uptake. With a range of novel techniques increasingly being used for efficient extraction processes to valorise marine algal biomass, the approach adopted in this study can be employed for other innovative technologies and approaches to determine their suitability prior to commercial exploitation. This study demonstrates the importance of a sustainable extraction technological approach that can aid policy development in an environmentally, economic evidenced, and health-benefit-based manner. The joint approach to economically viable and sustainable technology usage can help policymakers to encourage industrial adoption of technologies for sustainable production for a healthy lifestyle. However, this study is not without its limitations. It considers lab processes and equipment designed for research purposes, which, unlike the industrial-scale systems, do not reach ideal conditions for energy and chemical consumption that can maximize polyphenols extraction. In addition, affordability and challenges of implementation on an industrial scale are not taken into account. Therefore, the scale-up scenarios can only demonstrate an early-stage comparison of the process steps and variables. Moreover, in terms of execution of the study, no infrastructure-related processes such as the production of lab-scale equipment as well as no transportation of any of the materials involved were included, further limiting the findings. Further investigations are thus called for to incorporate facets related to the environmental and economic impacts into the evaluation of extraction processes using novel technologies.

Author Contributions: Conceptualization, A.P. and G.R.; methodology, A.P.; software, B.K.T.; validation, A.P. and G.R.; formal analysis, A.P.; investigation, G.R.; resources, G.R.; data curation, A.P.; writing-original draft preparation, A.P.; writing—review and editing, G.R. and B.K.T.; visualization, A.P.; supervision, G.R.; project administration, G.R.; funding acquisition, G.R. and B.K.T. All authors have read and agreed to the published version of the manuscript.

Funding: The authors acknowledge the financial support from Science Foundation Ireland (SFI) for this research work [grant numbers: 16/RC/3889]. 
Institutional Review Board Statement: Not applicable.

Informed Consent Statement: Not applicable.

Data Availability Statement: Not applicable.

Acknowledgments: Author G.R. would like to acknowledge the support received from the Higher Education Authority Technological University Transformation Fund (TUTF) under REiSA project at MTU.

Conflicts of Interest: The authors declare no conflict of interest.

\section{References}

1. Lee, S. Strategic design of delivery systems for nutraceuticals. In Nanotechnology Applications in Food; Grumezescu, A.M., Oprea, A.E., Eds.; Elsevier: Amsterdam, The Netherlands, 2017; pp. 65-86.

2. Bayir, A.G.; Aksoy, A.N.; Koçyiğit, A. The Importance of Polyphenols as Functional Food in Health. Bezmialem Sci. 2019, 7, 157-164. [CrossRef]

3. Bernal, J.; Mendiola, J.; Ibáñez, E.; Cifuentes, A. Advanced analysis of nutraceuticals. J. Pharm. Biomed. Anal. 2011, 55, 758-774. [CrossRef] [PubMed]

4. FAO. Nutrition and Food Systems, A Report by High Level Panel of Experts on Food Security and Nutrition; Food and Agriculture Organization: Rome, Italy, 2016.

5. $\quad$ Baghel, R.S.; Suthar, P.; Gajaria, T.K.; Bhattacharya, S.; Anil, A.; Reddy, C. Seaweed biorefinery: A sustainable process for valorising the biomass of brown seaweed. J. Clean. Prod. 2020, 263, 121359. [CrossRef]

6. Binsi, P.; Zynudheen, A. Functional and nutraceutical ingredients from marine resources. In Value-Added Ingredients and Enrichments of Beverages; Grumezescu, A.M., Holban, M., Eds.; Elsevier: Amsterdam, The Netherlands, 2019 ; pp. 101-171.

7. Fuad, N.; Omar, R.; Kamarudin, S.; Harun, R.; Idris, A.; Wan Azlina, W.A.K.G. Mass harvesting of marine microalgae using different techniques. Food Bioprod. Process. 2018, 112, 169-184. [CrossRef]

8. Sudhakar, M.; Kumar, B.R.; Mathimani, T.; Arunkumar, K. A review on bioenergy and bioactive compounds from microalgae and macroalgae-sustainable energy perspective. J. Clean. Prod. 2019, 228, 1320-1333. [CrossRef]

9. Gupta, C.; Prakash, D. Nutraceuticals from microbes of marine sources. In Nutraceuticals-Past, Present and Future; Hueda, M.C., Ed.; IntechOpen: London, UK, 2019.

10. European Commission. Food from the Oceans, High Level Group of Scientific Advisors, European Commission, Scientific Opinion; No. 3/2017; European Commission: Brussels, Belgium, 2017; pp. 1-80.

11. DAFM. FoodWise 2025: Challenge, Ambition, Opportunity. Local Roots Global Reach; Department of Agriculture, Food and the Marine (DAFM): Dublin, Ireland, 2020.

12. Garcia-Vaquero, M.; Rajauria, G.; O'doherty, J.; Sweeney, T. Polysaccharides from macroalgae: Recent advances, innovative technologies and challenges in extraction and purification. Food Res. Int. 2017, 99, 1011-1020. [CrossRef]

13. Kadam, S.U.; Tiwari, B.K.; O'Donnell, C.P. Application of novel extraction technologies for bioactives from marine algae. J. Agric. Food Chem. 2013, 61, 4667-4675. [CrossRef]

14. Garcia-Vaquero, M.; Ummat, V.; Tiwari, B.; Rajauria, G. Exploring Ultrasound, Microwave and Ultrasound-Microwave Assisted Extraction Technologies to Increase the Extraction of Bioactive Compounds and Antioxidants from Brown Macroalgae. Marine Drugs 2020, 18, 172-186. [CrossRef]

15. Náthia-Neves, G.; Vardanega, R.; Meireles, M.A.A. Extraction of natural blue colorant from Genipa americana L. using green technologies: Techno-economic evaluation. Food Bioprod. Process. 2019, 114, 132-143. [CrossRef]

16. Vauchel, P.; Colli, C.; Pradal, D.; Philippot, M.; Decossin, S.; Dhulster, P.; Dimitrov, K. Comparative LCA of ultrasound-assisted extraction of polyphenols from chicory grounds under different operational conditions. J. Clean. Prod. 2018, 196, 1116-1123. [CrossRef]

17. Sanz, V.; Flórez-Fernández, N.; Domínguez, H.; Torres, M.D. Clean technologies applied to the recovery of bioactive extracts from Camellia sinensis leaves agricultural wastes. Food Bioprod. Process. 2020, 122, 214-221. [CrossRef]

18. Priyadarshini, A.; Rajauria, G.; O'Donnell, C.P.; Tiwari, B.K. Emerging food processing technologies and factors impacting their industrial adoption. Crit. Rev. Food Sci. Nutr. 2019, 59, 1-20. [CrossRef]

19. Allen, D.T.; Shonnard, D.R. Green engineering: Environmentally conscious design of chemical processes and products. Am. Inst. Chem. Eng. AIChE J. 2001, 47, 1906. [CrossRef]

20. Grossmann, I.E.; Westerberg, A.W. Research challenges in process systems engineering. AIChE J. 2000, 46, 1700-1703. [CrossRef]

21. Burgess, A.A.; Brennan, D.J. Application of life cycle assessment to chemical processes. Chem. Eng. Sci. 2001, 56, 2589-2604. [CrossRef]

22. Jacquemin, L.; Pontalier, P.-Y.; Sablayrolles, C. Life cycle assessment (LCA) applied to the process industry: A review. Int. J. Life Cycle Assess. 2012, 17, 1028-1041. [CrossRef]

23. Gillani, S.T.; Belaud, J.-P.; Sablayrolles, C.; Vignoles, M.; Le Lann, J.-M. Review of life cycle assessment in agro-chemical processes. Chem. Prod. Process Modeling 2010, 5, 1-26. [CrossRef] 
24. Aziz, N.I.H.A.; Hanafiah, M.M.; Gheewala, S.H. A review on life cycle assessment of biogas production: Challenges and future perspectives in Malaysia. Biomass Bioenergy 2019, 122, 361-374. [CrossRef]

25. Crossin, E. Life cycle assessment of a mallee eucalypt jet fuel. Biomass Bioenergy 2017, 96, 162-171. [CrossRef]

26. Modahl, I.S.; Brekke, A.; Valente, C. Environmental assessment of chemical products from a Norwegian biorefinery. J. Clean. Prod. 2015, 94, 247-259. [CrossRef]

27. Siegl, S.; Laaber, M.; Holubar, P. Green electricity from biomass, part I: Environmental impacts of direct life cycle emissions. Waste Biomass Valorization 2011, 2, 267-284. [CrossRef]

28. Barjoveanu, G.; Pătrăuțanu, O.-A.; Teodosiu, C.; Volf, I. Life cycle assessment of polyphenols extraction processes from waste biomass. Sci. Rep. 2020, 10,1-12.

29. Gonzalez-Garcia, S.; Gullón, B.; Moreira, M.T. Environmental assessment of biorefinery processes for the valorization of lignocellulosic wastes into oligosaccharides. J. Clean. Prod. 2018, 172, 4066-4073. [CrossRef]

30. Gao, W.; Sun, Z.; Cao, H.; Ding, H.; Zeng, Y.; Ning, P.; Xu, G.; Zhang, Y. Economic evaluation of typical metal production process: A case study of vanadium oxide production in China. J. Clean. Prod. 2020, 256, 120217. [CrossRef]

31. Liu, X.; Tanaka, M.; Matsui, Y. Economic evaluation of optional recycling processes for waste electronic home appliances. J. Clean. Prod. 2009, 17, 53-60. [CrossRef]

32. Kyriakopoulou, K.; Papadaki, S.; Krokida, M. Life cycle analysis of $\beta$-carotene extraction techniques. J. Food Eng. 2015, 167, 51-58 [CrossRef]

33. Agnhage, T.; Perwuelz, A.; Behary, N. Towards sustainable Rubia tinctorum L. dyeing of woven fabric: How life cycle assessment can contribute. J. Clean. Prod. 2017, 141, 1221-1230. [CrossRef]

34. Papadaki, S.; Kyriakopoulou, K.; Tzovenis, I.; Krokida, M. Environmental impact of phycocyanin recovery from Spirulina platensis cyanobacterium. Innov. Food Sci. Emerg. Technol. 2017, 44, 217-223. [CrossRef]

35. Carreira-Casais, A.; Otero, P.; Garcia-Perez, P.; Garcia-Oliveira, P.; Pereira, A.G.; Carpena, M.; Soria-Lopez, A.; Simal-Gandara, J.; Prieto, M.A. Benefits and drawbacks of ultrasound-assisted extraction for the recovery of bioactive compounds from marine algae. Int. J. Environ. Res. Public Health 2021, 18, 9153. [CrossRef]

36. Carciochi, R.A.; Dieu, V.; Vauchel, P.; Pradal, D.; Dimitrov, K. Reduction of environmental impacts of caffeine extraction from guarana by using ultrasound assistance. Food Bioprod. Process. 2021, 127, 266-275. [CrossRef]

37. Tao, Y.; Wu, Y.; Han, Y.; Chemat, F.; Li, D.; Show, P.L. Insight into mass transfer during ultrasound-enhanced adsorption/desorption of blueberry anthocyanins on macroporous resins by numerical simulation considering ultrasonic influence on resin properties. Chem. Eng. J. 2020, 380, 122530. [CrossRef]

38. Ummat, V.; Tiwari, B.K.; Jaiswal, A.K.; Condon, K.; Garcia-Vaquero, M.; O’Doherty, J.; O’Donnell, C.P.; Rajauria, G. Optimisation of Ultrasound Frequency, Extraction Time and Solvent for the Recovery of Polyphenols, Phlorotannins and Associated Antioxidant Activity from Brown Seaweeds. Mar. Drugs 2020, 18, 250-264. [CrossRef]

39. ISO 14040; Environmental Management-Life Cycle Assessment-Part 1: Principles and Framework. International Organization for Standardization: Geneva, Switzerland, 2006; 3, 1-20.

40. Kaplan, R.; Anderson, S. Time-Driven Activity-Based Costing. Harv. Bus. Rev. 2004, 11, 4-45. [CrossRef]

41. Hoozée, S.; Bruggeman, W. Identifying operational improvements during the design process of a time-driven ABC system: The role of collective worker participation and leadership style. Manag. Account. Res. 2010, 21, 185-198. [CrossRef]

42. Rajasekaran, V. Cost Accounting; Pearson Education India: Delhi, India, 2010.

43. Demeere, N.; Stouthuysen, K.; Roodhooft, F. Time-driven activity-based costing in an outpatient clinic environment: Development, relevance and managerial impact. Health Policy 2009, 92, 296-304. [CrossRef]

44. Piotrowska, A.; Rao, M.A.; Scotti, R.; Gianfreda, L. Changes in soil chemical and biochemical properties following amendment with crude and dephenolized olive mill waste water (OMW). Geoderma 2011, 161, 8-17. [CrossRef]

45. Boechat, C.L.; Santos, J.A.G.; Accioly, A.M.d.A.; Bomfim, M.R.; dos Santos, A.C. Industrial and urban organic wastes increase soil microbial activity and biomass. Rev. Bras. Ciência Solo 2012, 36, 1629-1636. [CrossRef]

46. Farías-Campomanes, A.M.; Rostagno, M.A.; Meireles, M.A.A. Production of polyphenol extracts from grape bagasse using supercritical fluids: Yield, extract composition and economic evaluation. J. Supercrit. Fluids 2013, 77, 70-78. [CrossRef]

47. Prado, J.M.; Dalmolin, I.; Carareto, N.D.; Basso, R.C.; Meirelles, A.J.; Oliveira, J.V.; Batista, E.A.; Meireles, M.A.A. Supercritical fluid extraction of grape seed: Process scale-up, extract chemical composition and economic evaluation. J. Food Eng. 2012, 109, 249-257. [CrossRef]

48. Rosa, P.T.; Meireles, M.A.A. Rapid estimation of the manufacturing cost of extracts obtained by supercritical fluid extraction. J. Food Eng. 2005, 67, 235-240. [CrossRef]

49. Jiménez-Escrig, A.; Gómez-Ordóñez, E.; Rupérez, P. Brown and red seaweeds as potential sources of antioxidant nutraceuticals. J. Appl. Phycol. 2012, 24, 1123-1132. [CrossRef]

50. Montero, L.; del Pilar Sánchez-Camargo, A.; Ibáñez, E.; Gilbert-López, B. Phenolic compounds from edible algae: Bioactivity and health benefits. Curr. Med. Chem. 2018, 25, 4808-4826. [CrossRef] [PubMed]

51. Ganesan, A.R.; Tiwari, U.; Rajauria, G. Seaweed nutraceuticals and their therapeutic role in disease prevention. Food Sci. Hum. Wellness 2019, 8, 252-263. [CrossRef]

52. Saravacos, G.; Maroulis, Z. Food Process Economics. In Food Engineering Interfaces; Aguilera, J.M., Simpson, R., Welti-Chanes, J., Eds.; Springer: New York, NY, USA, 2010; pp. 219-236. 
53. Gwee, Y.L.; Yusup, S.; Tan, R.R.; Yiin, C.L. Techno-economic and life-cycle assessment of volatile oil extracted from Aquilaria sinensis using supercritical carbon dioxide. J. $\mathrm{CO}_{2}$ Util. 2020, 38, 158-167. [CrossRef]

54. Ochoa, S.; Durango-Zuleta, M.M.; Osorio-Tobón, J.F. Techno-economic evaluation of the extraction of anthocyanins from purple yam (Dioscorea alata) using ultrasound-assisted extraction and conventional extraction processes. Food Bioprod. Process. 2020, 122, 111-123. [CrossRef]

55. Galviz-Quezada, A.; Ochoa-Aristizábal, A.M.; Zabala, M.E.A.; Ochoa, S.; Osorio-Tobón, J.F. Valorization of iraca (Carludovica palmata, Ruiz \& Pav.) infructescence by ultrasound-assisted extraction: An economic evaluation. Food Bioprod. Process. 2019, 118, 91-102.

56. Zabot, G.L.; Bitencourte, I.P.; Tres, M.V.; Meireles, M. Process intensification for producing powdered extracts rich in bioactive compounds: An economic approach. J. Supercrit. Fluids 2017, 119, 261-273. [CrossRef]

57. Johner, J.C.; Hatami, T.; Zabot, G.L.; Meireles, M.A.A. Kinetic behavior and economic evaluation of supercritical fluid extraction of oil from pequi (Caryocar brasiliense) for various grinding times and solvent flow rates. J. Supercrit. Fluids 2018, 140, 188-195. [CrossRef]

58. Tufvesson, P.; Ekman, A.; Sardari, R.R.; Engdahl, K.; Tufvesson, L. Economic and environmental assessment of propionic acid production by fermentation using different renewable raw materials. Bioresour. Technol. 2013, 149, 556-564. [CrossRef] 